\title{
Effect of green leafy vegetables powder on anaemia and vitamin-A status of Ghanaian school children
}

\author{
Godfred Egbi ${ }^{*}$, Samuel Gbogbo², George Ekow Mensah", Mary Glover-Amengor ${ }^{3}$ and Matilda Steiner-Asiedu²
}

\begin{abstract}
Background: Nutritional anaemia and vitamin-A deficiency are public health issues confronting Ghanaian children. Their adverse effects are likely pronounced during the dry season when green leafy vegetables, rich-sources of iron and provitamin-A are scarce. This study assessed the effect of dried green leafy vegetables on anaemia and vitamin-A status of Ghanaian school children.

Method: This was 3 months pretest, posttest nutrition intervention study. Children 4-9 years were randomized to receive or not receive supplement. High Performance Liquid Chromatography and Haemocue hemoglobinometer were used to determine vitamin-A and haemoglobin concentrations respectively. Malaria-parasitaemia and helminthes were examined by Giemsa-staining and Kato-Katz respectively. Nutritional status was assessed by anthropometry. Student's t-test was used to establish significant differences between groups.

Results: At baseline, the mean haemoglobin concentrations of control and supplemental were $116.9 \pm 9.9 \mathrm{~g} / \mathrm{l}$ and $117.6 \pm 12.7 \mathrm{~g} / \mathrm{l}$ respectively. At end-line, it was $121.9 \pm 13.5 \mathrm{~g} / \mathrm{l}$ for supplemental and $113.4 \pm 8.5 \mathrm{~g} / \mathrm{l}$ for control, significant at $p=0.001$. At baseline prevalence of anaemia was 37.3 and $41.5 \%$ in control and supplemental respectively. At end-line it was $33.3 \%$ in supplemental against $57.5 \%$ in control, significant at $p=0.024$. At baseline mean retinol concentrations were $16.79 \pm 8.74 \mu \mathrm{g} / \mathrm{dl}$ and $16.97 \pm 7.74 \mu \mathrm{g} / \mathrm{dl}$ for control and supplemental respectively. Mean retinol concentrations for control and supplemental were $24.35 \pm 5.50 \mu \mathrm{g} / \mathrm{dl}$ and $26.96 \pm 6.86 \mu \mathrm{g} / \mathrm{dl}$ respectively at end-line. At end-line $60 \%$ of control against $64.0 \%$ of supplemental had low vitamin-A status. At end-line, anaemic-control had mean retinol concentration of $23.78 \pm 5.23 \mu \mathrm{g} / \mathrm{dl}$ and anaemic-supplemental had $27.46 \pm 7.28 \mu \mathrm{g} / \mathrm{dl}$. Prevalence of low vitamin-A status was 64.3 and $84.2 \%$ in anaemic-control and anaemic-supplemental respectively at baseline but it became 23.1 and $21.1 \%$ respectively, at end-line. The mean haemoglobin concentrations of anaemic-control and supplemental were $105.7 \pm 7.5 \mathrm{~g} / \mathrm{l}$ and $113.6 \pm 13.6 \mathrm{~g} / \mathrm{l}$ respectively at end-line. The change in prevalence of anaemia between the anaemic groups was $12.2 \%$, significant at $p=0.042$.
\end{abstract}

Conclusion: Consumption of green leafy vegetables powder increased mean haemoglobin and retinol concentrations of the study participants. It had the potential to minimize prevalence of anaemia and low vitamin-A status of study participants.

Keywords: Anaemia, Green leafy vegetable, Powder, School children, Vitamin-A, Deficiency, Prevalence

\footnotetext{
* Correspondence: gegbi@noguchi.ug.edu.gh

${ }^{1}$ Noguchi Memorial Institute for Medical Research, College of Health

Sciences, University of Ghana, P.O. Box LG 581, Legon, Accra, Ghana

Full list of author information is available at the end of the article
}

(c) The Author(s). 2018 Open Access This article is distributed under the terms of the Creative Commons Attribution 4.0 International License (http://creativecommons.org/licenses/by/4.0/), which permits unrestricted use, distribution, and reproduction in any medium, provided you give appropriate credit to the original author(s) and the source, provide a link to the Creative Commons license, and indicate if changes were made. The Creative Commons Public Domain Dedication waiver (http://creativecommons.org/publicdomain/zero/1.0/) applies to the data made available in this article, unless otherwise stated. 


\section{Background}

Anaemia affects averagely 800 million children and women worldwide [1]. In Sub Saharan Africa, about 83.5 million people are anaemic [2]. Anaemia and vitamin A deficiency are persistent nutritional problems of public health interest confronting Ghanaian children [3-6]. In Ghana, anaemia was the fourth cause of hospital admissions and the second factor contributing to mortality after a review of the disease profile and pathology reports in some hospitals [7]. Anaemia impairs children's mental, physical, social development and it is related to their poor academic performance [8]. The long effect of anaemia due to iron deficiency on Intelligence Quotient (IQ) is 1.73 points lower for every $10 \mathrm{~g} / \mathrm{l}$ decrease in haemoglobin levels at the early stage of life [9]. Anaemia is caused by multiple factors: nutritional and non-nutritional factors [10-12]. Nutritional anaemia is attributable to iron, vitamin $\mathrm{A}$, folate, vitamin $\mathrm{B}_{12}$, ascorbic acid and zinc deficiencies [13]. These nutrients deficiencies may be due to inadequate dietary intakes and poor bioavailability of these micronutrients. Poor bioavailability is the inhibitory effect of anti-nutritional factors such as polyphenols, tannins and phytates [13]. Inflammation, infection and genetic disorders (thalassaemia, sickle cell disease) which affect erythrocytes are other factors known to cause anaemia [14].

Vitamin-A deficiency contributes to nutritional anaemia. Linkage existed between vitamin-A deficiency and general anaemia such that anaemia prevalence reduced repeatedly during simultaneous vitamin-A, and iron supplementation $[15,16]$. It has also been shown that vitamin-A, and iron supplementation had positive impact on measures of vitamin-A and anaemia status in older children $[15,17]$. Vitamin-A deficiency is the most essential causes of avoidable childhood blindness and is a major contributor to morbidity and mortality from infections [18]. There have been attempts and there are still strategies to minimize the burden of anaemia among Ghanaian children. Most of these strategies include food fortification, dietary modification and diversification, access to and use of mosquito treated bed nets and nutrition education programs. Diets in developing countries are known to lack a wide range of micronutrients [19]. In tropical Africa where the daily diet is mainly composed of starchy staples, green leafy vegetables (GLVs) are the cheapest and most readily available source of micronutrients [20]. Several studies have been done on the nutritional value of many GLVs and it has been established that their consumption on regular basis may result in the reduction of micronutrients deficiencies leading to improvement in the nutrition and wellbeing of humans. It is reported that nearly 1000 edible vegetables exist in sub-Saharan Africa [21]. In Ghana, there are two seasons; the rainy and dry seasons. Green leafy vegetables are only available, accessible and affordable to most households during the rainy season. During the dry season, most rural household members have inadequate dietary intakes of micronutrients such as iron, zinc and pro vitamin-A (beta-carotene from GLVs) are virtually absent. They would be unable to meet their Recommended Dietary Allowances (RDA's) for micronutrients such as iron, folic acid, vitamin-A and zinc [22] which may exacerbate the problem of nutritional anaemia among Ghanaian school children. One strategy would be to process GLVs into products like powders that can be well preserved to ensure good keeping quality so that they can be available, accessible and affordable to most households in the dry season. Sun drying and oven (mechanical) drying are two options. Sun drying is the least expensive and most accessible way of food preservation in low income countries. Green leafy vegetable powder of Solanum macrocarpon (eggplant) and Amaranthus cruentus (amaranthus) are rich sources of iron, zinc and beta-carotene [20, 23, 24] so could contribute to the reduction of anaemia and Vitamin-A deficiency. Hence this study seeks to assess the effect of consumption of Composite Green Leafy Vegetable Powder (CGLVP) of Solanum macrocarpon and Amaranthus cruentus on anaemia and vitamin-A status of Ghanaian school children.

\section{Methods}

The study was a pretest posttest design. The participants were school children 4-9 years old. Inclusion and exclusion criteria were school children 4-9 years, not severely anaemic, not on any nutrient supplement and participating regularly in the Ghana Government School Feeding Program. Data on background characteristics (sex, age, occupation, education and monthly income) were obtained from parents of the study participants through interviews using combined open-ended and semi-structured questionnaires. Height and weight measurements were done according to standard procedures [25]. Duplicate weight measurements were taken to the nearest $0.1 \mathrm{~kg}$ using an electronic bathroom scale (Precision Health Scale UC-300 from A and D Company Limited, Higashi-Ikebukuro, Toshima-Ku, Tokyo, Japan). Each child's height was taken with a Plastic stadiometer in a standing position. Heights were taken in duplicates to the nearest $0.1 \mathrm{~cm}$. The mean of two readings was considered as the actual value for each participant.

Five millilitres of fasting venous blood was obtained from each participant by a phlebotomist into Eppendorf tubes without anticoagulants in the morning before breakfast. The blood samples were sent to the clinical laboratory of the Volta Regional Hospital (Trafalga), centrifuged and serum aliquots pipetted into Eppendorf 


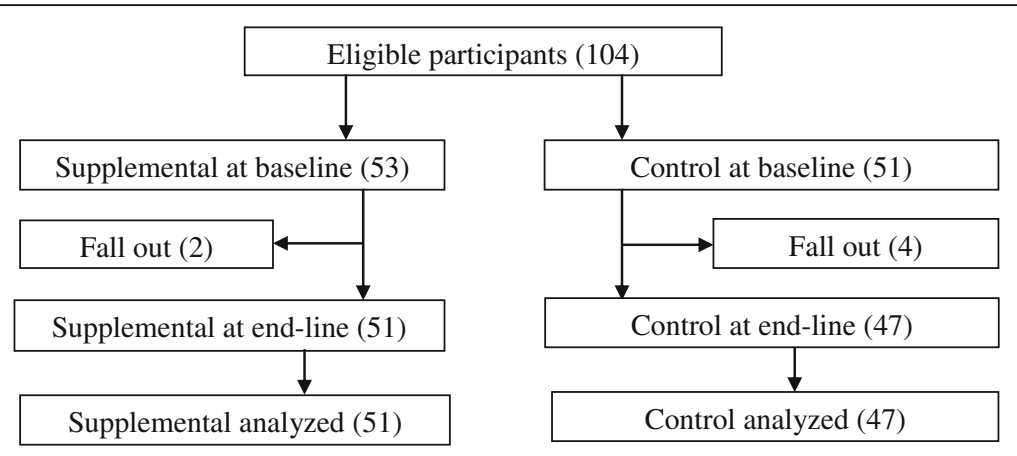

Fig. 1 Consort diagram of the study

tubes and stored below $-80^{\circ} \mathrm{C}$ until they were analyzed for vitamin-A. Parents helped collect $3 \mathrm{~g}$ (teaspoon size) of fresh stool sample from their wards participating in the study early in the morning before breakfast. The stool samples were immediately transported on ice to the microbiology-parasitology laboratory at Trafalga and examined for the presence of soil-transmitted helminthes with the Kato-Katz technique [26]. Prior to the distribution of stool containers, parents of participating children were educated on all the necessary safety measures and taken through the appropriate way to collect stool samples. Haemoglobin concentrations were assessed immediately in the field using a Hemocue Hemoglobinometer (Hemocue AB, Angelhom, Sweden). Haemoglobin values were taken to the nearest $0.1 \mathrm{~g} / \mathrm{l}$. Malaria parasitemia was examined in thin and thick blood film slides of participants using the Giemsa staining technique [26]. Children with severe anaemia (haemoglobin $<85 \mathrm{~g} / \mathrm{L}$ ) were excluded from the study but referred by the medical officer on the study team to the Ho municipal hospital for treatment. Children found with malaria parasitaemia were referred by the medical officer on the study team to the Ho municipal hospital to seek treatment. They were recruited into the study as they met the study inclusion and exclusion criteria.

Serum vitamin A concentration for each participant was determined by HPLC using a modified procedure of Noguchi Memorial Institute for Medical Research (NMIMR) protocol for vitamin A analysis in serum [27]. Initially $1 \mathrm{mg} / \mathrm{ml}$ standard retinol stock solution was prepared. A standard working solution of $1 \mu \mathrm{g} / \mathrm{ml}$ retinol standard was prepared from the stock solution. Serial dilutions of $0.5 \mu \mathrm{g} / \mathrm{ml}, 0.25 \mu \mathrm{g} / \mathrm{ml}, 0.125 \mu \mathrm{g} / \mathrm{ml}$ and $0.0625 \mu \mathrm{g} / \mathrm{ml}$ standard retinol solutions were made from $1.0 \mu \mathrm{g} / \mathrm{ml}$ of the standard working solution. Aliquots of $240 \mu \mathrm{l}$ of respective standard solutions were injected into the HPLC system and their peak areas determined. The standard curve was established by plotting mean peak area against respective mean standard concentration.
Frozen serum samples of the study participants were completely thawed for $60 \mathrm{~s}$. Duplicate aliquots of $120 \mu \mathrm{l}$ serum for every study participant was pipetted into $1.5 \mathrm{ml}$ Eppendorf tubes and $120 \mu \mathrm{l}$ of methanol added. The mixture was vortexed for $30 \mathrm{~s}$ to denature all protein materials present in the serum sample. Five hundred microliters of hexane was added and the resultant mixture was vortexed for $120 \mathrm{~s}$ to solubilize all the fat soluble components. Two hundred and fifty microliters of supernatant was pipetted into a clean $1.5 \mathrm{ml}$ Eppendorf tube and evaporated slowly and carefully under nitrogen gas to dryness. The residue was reconstituted with $120 \mu \mathrm{l}$ of methanol by vortexing for $20 \mathrm{~s}$. The reconstituted extracted sample was injected into an HPLC system and the peak area recorded. Duplicate determinations of peak areas were made on each serum sample and the average used to determine the serum retinol concentration in a sample. The HPLC was calibrated such that the retinol component eluted at $4.5 \mathrm{~min}$ after injection. The mobile phase was methanol (HPLC grade) and the stationary phase is Purospher STAR RP-18 endcapped $(5 \mu \mathrm{m})$ Hibar $^{\circ}$ RT 250-4,6 HPLC column. The operation wavelength was $350 \mathrm{~nm}$ (Figure 1).

\section{Composite green leafy vegetable powder preparation}

Leafy vegetables of Solanum macrocarpon (eggplant) and Amaranthus cruentus (amaranthus) leaves were purchased from farmers engaged in urban vegetables market gardening. Each vegetable sample was washed in clean water, $1 \%$ saline for $3 \mathrm{~min}$, rinsed with clean tap water and dried in a locally manufactured mechanical oven at $45{ }^{\circ} \mathrm{C}$ for $10 \mathrm{~h}$. The dried leaves were milled into fine powder with a blender. One hundred and sixty grams of powdered Solanum macrocarpon and same quantity of Amaranthus cruentus were weighed and mixed thoroughly with a cake mixer. Two hundred and thirty grams of the mixed product, (CGLVP) was packaged in airtight plastic (polythene) bags and stored in cardboard boxes. 


\section{Intervention feeding}

Beans and tomato stews and groundnut soup each was prepared with, tomato paste (200 g), granulated pepper (15 g), onion paste (35 g), smoked anchovies powder $(100 \mathrm{~g})$ and iodized salt $(40 \mathrm{~g})$ with or without $230 \mathrm{~g}$ of Composite Green Leafy Vegetable Powder (CGLVP). Groundnut oil (400 g) was used to prepare either beans or tomato stew and Groundnut paste (400 g) was used to prepare the groundnut soup. Each participant was served $50 \mathrm{~g}$ of tomato stew with or without CGLVP thrice a week, $100 \mathrm{~g}$ of beans stew with or without CGLVP and $95 \mathrm{~g}$ of groundnut soup with or without CGLVP once a week for a period of 3 months. Chemical analysis established that tomato stew, beans stew and groundnut soup alone provided $3.0 \pm 0.02 \mathrm{mg}, 5.15 \pm 1.01 \mathrm{mg}$ and $2.8 \pm 0.2 \mathrm{mg}$ iron respectively to each participant in the control group. Tomato + CGLVP stew, beans + CGLVP stew and groundnut + CGLVP soup provided $9.7 \pm 0.1 \mathrm{mg}$, $14.5 \pm 1.1 \mathrm{mg}$ and $6.9 \pm 0.1 \mathrm{mg}$ iron respectively to each study participant in the experimental group. The supplemental stews and soup (Tomato + CGLVP stew, beans + CGLVP stew and groundnut + CGLVP soup) provided an average intake of $498.1 \mu \mathrm{g}$ beta-carotene (41.5 RE)/day against $275 \mu \mathrm{g}-445 \mu \mathrm{g}$ beta-carotene (22.9 - 30RE) which is the estimated average requirement of pro vitamin A for 4-9 years children [22]. At the end of 3 months intervention feeding, blood and stool samples were collected, examined and analyzed for the various factors just as done at baseline.

\section{Data analysis}

Data at baseline and at the end of the study were entered into Epi Info Version 7 software, cleaned and exported to SPSS version 22.0 for analysis. Children were classified as anaemic with haemoglobin concentration below $110 \mathrm{~g} / \mathrm{l}$ and $115 \mathrm{~g} / \mathrm{l}$ for children 5-59 months and 5-11 years respectively [28]. The cut off used to identify participants with low vitamin-A status was serum retinol concentration $<20 \mu \mathrm{g} / \mathrm{dl}$. Summary data were presented with descriptive statistics as means plus standard deviations, frequencies and percentages. Data comparison within each group was done for differences in anthropometric measures, haematological and biochemical variables using paired t-tests. Between groups significant or non-significant differences for continuous variables were carried out using independent t-test. Chi-square test was used to establish differences in percentages or proportions for categorical variables between groups. Binary logistic regression analysis was done to identify factors related to anaemia among the study participants. Significant differences were set at $p<0.05$ level.

\section{Results}

The characteristics of the study participants are shown in Table 1. The mean age was between 6.7-7.3 years. At baseline, the prevalence of malaria parasitaemia was comparatively similar in the range of $34.0-37.0 \%$. It was $40.4 \%$ in the controls and $39.6 \%$ in the experimental (supplemental) at the end of the study (end-line). Hookworm infestation was $1.0 \%$ at baseline and absent at end-line. There was high patronage of treated mosquito net use in the range of $86-91 \%$. Majority of the study participants and their household members (83-88\%) were beneficiaries of National Health Insurance Scheme (NHIS). Most parents (or guardians), 94-96\% had formal education (Table 1). As shown in Table 2, the mean haemoglobin concentration of the supplemental group was $121.9 \pm 13.5 \mathrm{~g} / \mathrm{l}$ and that of the control was $113.4 \pm 8.5 \mathrm{~g} / \mathrm{l}$ at the end of the study. The mean value for the supplemental group was significantly different from that of the control group, $p<0.05$. The prevalence of anaemia among the control group (57.5\%) was higher than the prevalence among the supplemental group (33.3\%), Table 2. The mean serum retinol concentration for the control and the supplemental groups at the start of the study were $16.79 \pm 8.74 \mu \mathrm{g} / \mathrm{dl}$ and $16.97 \pm 7.74 \mu \mathrm{g} / \mathrm{dl}$ respectively (Table 3 ). The mean serum concentration increased to $24.35 \pm 5.50 \mu \mathrm{g} / \mathrm{dl}$ in the control group and to $26.96 \pm 6.86 \mu \mathrm{g} / \mathrm{dl}$ in the supplemental group. The results (Table 3) show that at baseline 60.0 and $64.0 \%$ of the participants in the control and supplemental groups respectively had low vitamin A status. The percentage of participants with low vitamin A status declined to $18.2 \%$ in the control and $18.8 \%$ in the supplemental group at the end-line. The percentage of participants with normal vitamin A status in the control was $40.0 \%$ at baseline. It was $34.0 \%$ in the supplemental group. It increased to $84.0 \%$ in the control and to $87.0 \%$ in the supplemental group at the end-line, Table 3 . Table 4 shows the post vitamin A and anaemia status of anaemic participants before the start of the nutrition intervention study. At baseline there was no statistical difference in the mean retinol of both groups. Anaemic participants in the control group (anaemic-control) had mean serum retinol concentration of $23.78 \pm 5.23 \mu \mathrm{g} / \mathrm{dl}$ whilst the anaemic participants in the supplemetal group (anaemic-supplemental) had mean retinol concentration of $27.46 \pm$ $7.28 \mu \mathrm{g} / \mathrm{dl}$ at the end of the study. The anaemic-control had prevalence of low vitamin A as $64.3 \%$ at baseline whilst the anaemic-supplemental had it as $84.2 \%$ (Table 4). At end-line, low vitamin A prevalence was $23.1 \%$ in the anaemic-control and $21.1 \%$ in the anaemic-supplemental. Between group difference of difference in low vitamin A status was $21.9 \%$ (Table 4 ), statistically significant, $p=0.046$. The anaemic-control had mean haemoglobin concentration of $106.6 \pm 5.1 \mathrm{~g} / \mathrm{l}$ at baseline whilst anaemic-supplemental 
Table 1 Baseline and household characteristics of study participants

\begin{tabular}{|c|c|c|c|c|}
\hline \multirow[t]{3}{*}{ Factor } & \multicolumn{4}{|l|}{ Treatment } \\
\hline & Control $(n=51)$ & $\operatorname{CGLVP}(n=53)$ & Difference & $P$-value \\
\hline & $($ Mean $\pm S D)$ & $($ Mean \pm SD) & & \\
\hline Age (years) & $7.3 \pm 1.7$ & $6.7 \pm 1.8$ & 0.6 & 0.081 \\
\hline \multicolumn{5}{|l|}{ Gender (\%) } \\
\hline Boys & 51.0 & 50.9 & 0.1 & 0.765 \\
\hline Girls & 49.0 & 49.1 & 0.1 & 0.761 \\
\hline \multicolumn{5}{|l|}{ Anthropometric indices } \\
\hline Weight (kg) & $21.6 \pm 3.9$ & $22.9 \pm 4.9$ & 1.4 & 0.113 \\
\hline Height (cm) & $117.1 \pm 11.3$ & $120.6 \pm 11.1$ & 3.6 & 0.110 \\
\hline Weight-for-age z score & $-0.485 \pm 0.92$ & $-0.731 \pm 0.91$ & 0.246 & 0.193 \\
\hline Height-for-age z score & $-0.722 \pm 1.15$ & $-0.592 \pm 1.17$ & 0.130 & 0.567 \\
\hline Body Mass Index $\left(\mathrm{kg} / \mathrm{m}^{2}\right)$ & $-0.388 \pm 0.92$ & $-0.176 \pm 0.91$ & 0.212 & 0.134 \\
\hline Stunting (\%) & 17.6 & 13.2 & 4.4 & 0.530 \\
\hline Wasting (\%) & 15.7 & 11.3 & 4.4 & 0.514 \\
\hline Thinness (\%) & 3.9 & 5.7 & 1.8 & 0.281 \\
\hline Overweight (\%) & 3.9 & 3.8 & 0.1 & 0.689 \\
\hline Malaria parasitaemia (\%) & 37.3 & 34.0 & 3.3 & 0.726 \\
\hline \multicolumn{5}{|l|}{ Mosquito net use (\%) } \\
\hline Yes & $(86.3)$ & $(90.6)$ & & 0.491 \\
\hline No & $(13.7)$ & $(9.4)$ & & \\
\hline \multicolumn{5}{|c|}{ Beneficiary of National Health Insurance Scheme (\%) } \\
\hline Yes & 88.3 & 83.0 & & 0.452 \\
\hline No & 11.7 & 17.0 & & \\
\hline \multicolumn{5}{|l|}{ Parental education (\%) } \\
\hline Formal education & 94.1 & 96.2 & & 0.712 \\
\hline Informal education & 5.9 & 3.8 & & \\
\hline \multicolumn{5}{|l|}{ Parental occupation (\%) } \\
\hline Formal sector & 11.8 & 1.9 & & 0.110 \\
\hline Informal sector & 88.2 & 98.1 & & \\
\hline
\end{tabular}

$P$-values significant at $p<0.05$ using student t-test, otherwise chi-square test

had mean haemoglobin concentration of $104.9 \pm 8.2 \mathrm{~g} / \mathrm{l}$. At the end-line, the anaemic-control had mean haemoglobin concentration of $105.7 \pm 7.5 \mathrm{~g} / \mathrm{l}$ and the supplemental had it as $113.6 \pm 13.6 \mathrm{~g} / \mathrm{l}$ (Table 4). The prevalence of anaemia among the anaemic-control was $46.3 \%$ at baseline. It was $53.7 \%$ in the anaemic-supplemental. At the end of the study prevalence of anaemia was $34.1 \%$ in the anaemic-control and $29.3 \%$ (Table 4) in the anaemic-supplemental. The results (Table 5) showed household income, infection status, stunting status and intervention diet were the factors linked to the anaemia status of the participants in this study. Thus non-consumption of composite green leafy vegetables powder was significantly and negatively associated with anaemia, $p<0.05$. Malaria parasitaemia was prevalent among the children in both groups. There was no significant difference in the level of malaria parasitaemia in the participants in the control and the supplemental groups at the beginning and at end-line.

\section{Discussion}

This is one of few studies done with green leafy vegetables in Ghana [29, 30] and the first in the study area that investigated the effect of composite leafy vegetable powder on the anaemia and vitamin A status of school children. The baseline data showed prevalence of anaemia (39.4\%) and low vitamin A levels (63.5\%) among the children. The present findings of the study like previous studies across various regions of Ghana had showed that prevalence of anaemia among school aged children in the southern and northern sectors of Ghana is of public health interest [3, 4, 31-33]. Anaemia is attributable to the influence of nutritional and anti-nutritional factors 
Table 2 Mean haemoglobin levels and prevalence of anaemia among study participants

\begin{tabular}{|c|c|c|c|c|}
\hline \multirow[t]{3}{*}{ Factor } & \multicolumn{4}{|l|}{ Treatment } \\
\hline & \multirow{2}{*}{$\begin{array}{l}\text { Control } \\
\mathrm{n}(\text { Mean } \pm \mathrm{SD})\end{array}$} & CGLVP & \multirow[t]{2}{*}{ Difference } & \multirow[t]{2}{*}{$P$-value } \\
\hline & & $\mathrm{n}($ Mean $\pm \mathrm{SD})$ & & \\
\hline \multicolumn{5}{|c|}{ Haemoglobin concentration (g/l) } \\
\hline Baseline & $51(116.9 \pm 9.9)$ & $53(117.6 \pm 12.7)$ & $0.7 \pm 2.5$ & 0.747 \\
\hline End-line & $47(113.4 \pm 8.5)$ & $51(121.9 \pm 13.5)$ & $8.5 \pm 4.5$ & 0.001 \\
\hline Difference & $-3.5 \pm 1.4$ & $4.3 \pm 0.8$ & $7.8^{\mathrm{a}}$ & 0.028 \\
\hline$P$-value ${ }^{1}$ & 0.160 & 0.026 & - & - \\
\hline Effectiveness (\%) & -3.0 & 3.7 & 6.7 & - \\
\hline \multicolumn{5}{|c|}{ Prevalence of anaemia (haemoglobin conc. < $115 \mathrm{~g} / \mathrm{l}$ ), (\%) } \\
\hline Baseline & 37.3 & 41.5 & 4.2 & 0.657 \\
\hline End-line & 57.5 & 33.3 & 24.2 & 0.024 \\
\hline Difference & -20.2 & 8.2 & $28.4^{\mathrm{a}}$ & 0.011 \\
\hline$P$-value ${ }^{1}$ & 0.294 & 0.030 & - & - \\
\hline Effectiveness (\%) & -54.2 & 19.8 & 74 & - \\
\hline
\end{tabular}

$P$-values significant at 0.05 using student-t test otherwise chi-square test

Negative values in table shows reduction in prevalence or means

*P-value for between group comparison

${ }^{1} P$-value for within group comparison

${ }^{\text {a }}$ Difference in difference values

Table 3 Serum retinol levels and prevalence of vitamin A deficiency among study participants

\begin{tabular}{|c|c|c|c|c|}
\hline \multirow[t]{3}{*}{ Factor } & \multicolumn{4}{|l|}{ Treatment } \\
\hline & \multirow{2}{*}{$\begin{array}{l}\text { Control } \\
\text { n (Mean } \pm S D)\end{array}$} & CGLVP & \multirow[t]{2}{*}{ Diff $^{a}$} & \multirow[t]{2}{*}{$P$-value* } \\
\hline & & $\mathrm{n}($ Mean \pm SD) & & \\
\hline \multicolumn{5}{|c|}{ Serum retinol concentration $(\mu \mathrm{g} / \mathrm{dl})$} \\
\hline Baseline & $46(16.79 \pm 8.74)$ & $50(16.97 \pm 7.74)$ & $0.18 \pm 1.01$ & 0.907 \\
\hline End-line & $44(24.35 \pm 5.50)$ & $46(26.96 \pm 6.86)$ & $2.61 \pm 1.36$ & 0.065 \\
\hline Difference & $6.57 \pm 1.74$ & $9.18 \pm 1.57$ & $2.43^{\mathrm{a}}$ & 0.067 \\
\hline$P$-value ${ }^{1}$ & 0.001 & 0.0001 & - & - \\
\hline Effectiveness (\%) & 39.1 & 54.1 & 15.0 & - \\
\hline \multicolumn{5}{|c|}{ Low vitamin A status (serum retinol conc. $<20$ mg/dl) (\%) } \\
\hline Baseline & 60.9 & 66.0 & 5.1 & 0.062 \\
\hline End-line & 15.9 & 13 & -2.9 & 0.084 \\
\hline Difference & -45.0 & -53.0 & $-8.0^{\mathrm{a}}$ & 0.056 \\
\hline Effectiveness (\%) & -73.9 & -80.3 & -6.4 & - \\
\hline \multicolumn{5}{|c|}{ Adequate vitamin A status (serum retinol conc. $20-<50$ mg/dl) (\%) } \\
\hline Baseline & 40.0 & 34.0 & -6.0 & 0.058 \\
\hline End-line & 84.0 & 87.0 & 3.0 & 0.081 \\
\hline Difference & 44.0 & 53.0 & $9.0^{\mathrm{a}}$ & 0.053 \\
\hline Effectiveness (\%) & 104.5 & 125.8 & 21.3 & - \\
\hline
\end{tabular}

$P$-values significant at 0.05 using student-t test otherwise chi-square test

Negative values in table shows reduction in prevalence or means

${ }^{*} P$-value for between group comparison

${ }^{1} P$-value for within group comparison

a Difference in difference values 
Table 4 Post vitamin A and anaemia status of participants anaemic before the intervention study

\begin{tabular}{|c|c|c|c|c|}
\hline \multirow[t]{3}{*}{ Factor } & \multicolumn{4}{|l|}{ Treatment } \\
\hline & \multirow{2}{*}{$\begin{array}{l}\text { Control }(n=19) \\
\mathrm{n}(\text { Mean } \pm \text { SD) }\end{array}$} & CGLVP $(n-22)$ & \multirow[t]{2}{*}{ Diff $^{a}$} & \multirow[t]{2}{*}{$P$-value* } \\
\hline & & $\mathrm{n}($ Mean $\pm \mathrm{SD})$ & & \\
\hline \multicolumn{5}{|c|}{ Serum retinol concentration $(\mu \mathrm{g} / \mathrm{dl})$} \\
\hline Baseline & $19(16.63 \pm 7.59)$ & $22(14.39 \pm 5.40)$ & $-2.24 \pm 1.19$ & 0.457 \\
\hline End-line & $18(23.78 \pm 5.23)$ & $13(27.46 \pm 7.28)$ & $3.68 \pm 2.05$ & 0.089 \\
\hline Difference & $7.15 \pm 2.36$ & $13.07 \pm 1.88$ & $5.92 \pm 0.48^{\mathrm{a}}$ & 0.047 \\
\hline$P$-value ${ }^{1}$ & 0.001 & 0.0001 & - & - \\
\hline Effectiveness (\%) & 43.0 & 90.8 & 47.8 & - \\
\hline \multicolumn{5}{|c|}{ Prevalence of low vitamin A (serum retinol conc. $<20 \mu \mathrm{g} / \mathrm{dl}$ ) (\%) } \\
\hline Baseline & 64.3 & 84.2 & 19.9 & 0.049 \\
\hline End-line & 23.1 & 21.1 & -2.0 & 0.892 \\
\hline Difference & -41.2 & -63.1 & $-21.9^{a}$ & 0.041 \\
\hline Effectiveness (\%) & -64.1 & -74.9 & -10.8 & - \\
\hline \multicolumn{5}{|c|}{ Haemoglobin concentration (g/l) } \\
\hline Baseline & $19(106.6 \pm 5.1)$ & $22(104.9 \pm 8.2)$ & $-1.7 \pm 3.1$ & 0.450 \\
\hline End-line & $14(105.7 \pm 7.5)$ & $12(113.6 \pm 13.6)$ & $7.9 \pm 6.1$ & 0.046 \\
\hline Difference & $-0.9 \pm 2.4$ & $8.7 \pm 5.4$ & $9.6 \pm 3.0^{\mathrm{a}}$ & 0.034 \\
\hline$P$-value ${ }^{1}$ & 0.489 & 0.011 & - & - \\
\hline Effectiveness (\%) & -0.8 & 8.3 & 9.1 & - \\
\hline \multicolumn{5}{|c|}{ Prevalence of anaemia $(\mathrm{Hb}<115 \mathrm{~g} / \mathrm{l})(\%), N=41$} \\
\hline Baseline & $19(46.3)$ & $22(53.7)$ & 7.4 & .062 \\
\hline End-line & $14(34.1)$ & $12(29.3)$ & -4.8 & 0.081 \\
\hline Difference & -12.2 & -24.4 & $-12.2^{\mathrm{a}}$ & 0.042 \\
\hline Effectiveness (\%) & -26.3 & -45.3 & -19.0 & - \\
\hline
\end{tabular}

$P$-values significant at 0.05 using student-t test otherwise chi-square test Negative values in table shows reduction in prevalence or means

*P-value for between group comparison

${ }^{1} P$-value for within group comparison

${ }^{a}$ Difference in difference values

$[10,11]$. The current study showed infection (malaria parasitaemia) existed among the children and they consumed mostly plant based diets made of staple cereals and legumes. These are rich sources of anti-nutritional factors such as polyphenols, tannins and phytates, known inhibitors of iron and zinc absorption and bioavailability [13]. The prevalence of vitamin-A deficiency among the children in the current study is above the level reported previously [4]. The analyzed data showed that the mean haemoglobin concentration of the children who consumed Composite Green Leafy Vegetable Powder (CGLVP) increased significantly over that of those who consumed only the normal stew and soup provided by the school feeding program. There was a $3.5 \mathrm{~g} / \mathrm{l}$ decline in the mean haemoglobin concentration within the control group whilst the mean haemoglobin concentration increased by $4.3 \mathrm{~g} / \mathrm{l}$ within the experimental group. Previous studies demonstrated that vitamin A supplementation or fortification in controlled intervention studies increased the haemoglobin concentrations of preschool children [32]. The present study demonstrated that dietary modification of stew and soup with CGLVP; provitamin A and nonhaeme iron rich green leafy vegetable powder increased haemoglobin concentration of school aged children. The findings demonstrated that consumption of CGLVP minimized the prevalence of anaemia by $8.2 \%$ among the participants whilst consumption of the normal stews and soup provided by the school feeding program resulted in $20.2 \%$ rise in the prevalence of anaemia among the study participants. At the end of the study, the findings indicated that prevalence of anaemia was significantly higher among the control group compared to the supplemental group. Mean serum retinol concentration improved significantly within the two study groups. The likely consumption of palm fruit products at the household level aside the school lunch meal might have caused the significant increase in the mean retinol concentrations of both study groups. The later part of the 
Table 5 Factors associated with anaemia among the study participants

\begin{tabular}{llll}
\hline Factor & Odd Ratio & $95 \%$ Cl & $P$-value \\
\hline Age & 0.9 & $0.75-1.3$ & 0.719 \\
Gender & & & \\
$\quad$ Boys & 0.7 & $0.27-1.7$ & 0.461 \\
$\quad$ Girls & 1 & Reference & \\
Household Income & & & \\
$\quad$ SGHC 500 & 2.5 & $0.25-24.2$ & 0.440 \\
$\quad>$ GHC500 & 1 & Reference & \\
Infection Status & & & \\
$\quad \begin{array}{l}\text { Malaria Presence } \\
\text { Malaria Absence }\end{array}$ & 1.4 & $0.59-3.5$ & 0.421 \\
Stunted & 1 & Reference & \\
$\quad \begin{array}{l}\text { Yes(HAZ -2 SD) } \\
\text { No(HAZ -2 SD) }\end{array}$ & 1.2 & & 0.751 \\
Intervention diet & 1 & Reference & \\
$\quad \begin{array}{l}\text { No powder } \\
\text { Powder }\end{array}$ & 2.8 & $1.1-6.9$ & 0.036 \\
\hline
\end{tabular}

Statistical significance set at $p<0.05$, child age was adjusted for, OR Odd Ratio

study period coincided with the onset of palm fruit harvest. These intakes were confounders beyond the control of the intervention program. CGLVP consumption increased the mean serum retinol concentration of study participants by $2.4 \mu \mathrm{g} / \mathrm{dl}$ over the mean serum retinol concentration of the control group but this was not statistically significant, $p=0.067$. The consumption of CGLVP was $15 \%$ more effective in improving mean serum retinol concentration than non-consumption of CGLVP among the participants. Before the start of the nutrition intervention, both the control and CGLVP groups had mean serum retinol concentration $(17.0 \mu \mathrm{g} / \mathrm{dl})$, considered as marginal vitamin A status (serum retinol concentration 10 $-20 \mu \mathrm{g} / \mathrm{dl})$, [18]. The current study findings agree with suggestions made in earlier studies $[34,35]$ that intervention strategies targeted at reducing both vitamin $\mathrm{A}$ and iron deficiencies would be more effective in reducing anaemia compared to those aimed at either of these micronutrients. The powder was $19 \%$ more effective in minimizing prevalence of anaemia among the anaemic supplemental participants compared to the anaemic control in the course of the intervention study. The mean change (difference of difference), in serum retinol concentration was $5.92 \pm 0.48 \mu \mathrm{g} / \mathrm{dl}$ for the anaemic participants. The composite leafy vegetable powder (CGLVP) stews and soup were $47.8 \%$ effective in causing this mean change in serum retinol concentration between the study participants in the two groups. The consumption of the CGLVP (supplemental) stews and soup lead to $21.9 \%$ change (otherwise difference in difference) in prevalence of low
vitamin-A status among the anaemic participants in the study. The CGLVP stews and soup were $11.0 \%$ effective in minimizing prevalence of low vitamin-A status among the anaemic participants. The public health significance of vitamin A deficiency (VAD) would be classified as severe at baseline, since the findings show that at least $20 \%$ of the study participants had vitamin A deficiency [18]. The baseline dietary data (not presented in results of the current paper) indicated minimal dietary diversity among the children. They consumed less meat and meat products, less dairy products, moderate fruits and vegetables. Previous studies provided a lot of evidence that linked vitamin A deficiency to less frequent consumption of vegetables, fruits, fish, meat and less varied household diet $[36,37]$. Under normal physiological conditions serum retinol concentration reflects body vitamin A status only when liver retinol stores are seriously depleted. Inflammation affects serum retinol concentration. Severe infections also cause a decrease in vitamin $\mathrm{A}$ intake which reflects low vitamin A status [38]. At the end of the study prevalence of low vitamin A status (serum retinol concentration $<20 \mu \mathrm{g} / \mathrm{dl}$ ) reduced greatly in both study groups but $3.8 \%$ more in the intervention group. The findings indicated that improvement in vitamin A status of participants in both study groups $(24.35-26.96 \mu \mathrm{g} / \mathrm{dl})$ resulting in 18.2 and $18.8 \% \mathrm{VAD}$ in the control and intervention groups. That was an indication that VAD would be categorized as moderate prevalence in terms of public health significance [18]. The addition of groundnut oil or coconut oil to the stews and soup promoted dietary fat intake of participants in both study groups. Dietary fat intake is known to improve bioavailability of dietary carotene [39, 40]. Consumption of CGLVP plus vegetable (groundnut or coconut oil) oil was $15 \%$ effective in reducing prevalence of low vitamin A status than normal stews and soup provided by the school feeding program. CGLVP consumption was also $21.3 \%$ more effective in promoting adequate vitamin A status (serum retinol concentration $20-<50 \mu \mathrm{g} / \mathrm{dl}$ ) among the participants. Non-consumption of CGLVP was strongly and significantly associated with anaemia among the children. Participants who did not consume CGLVP had 2.8 times higher risk of being anaemic compared to participants who consumed CGLVP. The findings demonstrated that household income was strongly associated with anaemia even though this association was not significant. Children who belonged to households with monthly income less than or equal to GH 500.00 had a higher risk ( 2.5 times) of being anaemic than children who belonged to households with monthly income more than GH 500.00. A previous study reported that consumption of nutrient rich foods among rural poor folks was inversely proportional to food prices [41] and probably directly related to income levels. Most often the income factor could be associated with the nutritional knowledge of the 
individual, household head and the home maker. The most significant factor associated with anaemia in this study was the intervention diet. Study participants who did not consume CGLVP had 2.8 times higher risk of becoming anaemic than children who consumed CGLVP.

\section{Limitation(s) to the study}

The study participants were children benefiting from the Ghana School Feeding Program. For this reason the findings could not be applied to children in non-school feeding program schools and also children not attending school. Dietary intake of palm fruit products at household levels towards the end of study could not be controlled and hence their influence might be a confounding factor to vitamin A status of the participants.

\section{Conclusion}

The consumption of composite green leafy vegetable powder increased the mean haemoglobin concentration significantly but not the mean serum vitamin A concentration of the study participants. It minimized the prevalence of anaemia among the participants. Composite green leafy vegetable powder has the potential to minimize prevalence of anaemia among the study participants.

\section{Abbreviations}

CGLVP: Composite green leafy vegetable powder; g/l: gram per litre; GLVs: Green leafy vegetables; HPLC: High performance liquid chromatography; IQ: Intelligence quotient; NMIMR: Noguchi Memorial Institute for Medical Research; RDAs: Recommended dietary allowances; VAD: Vitamin A deficiency

\section{Acknowledgements}

The authors appreciate the support in terms of laboratory equipment, office space and administrative services provided by the Noguchi Memorial Institute for Medical Research (NMIMR), College of Health Sciences, University of Ghana, Legon. We are also grateful to Dr. Winfred Ofosu the Medical Officer on the study team, Mr. Eric Harrison the coordinator of all field activities. We are also thankful to Miss Evelyn Boakye-Danquah, Mr. Stanley Afriyie, Miss Loobod Soma-mahme, Mr. Ebenezer Ofori-Attah and Mr. Osei Kwame Gabriel for their various roles in biological samples and data collection in the field, and analysis of samples at the parasitology and nutrition laboratories of NMIMR.

\section{Funding}

The funding for the study and this article came from the Nestle Foundation. This is greatly appreciated. Nestle Foundation played no role in the design of the study, data collection, data analysis or the write up of the study.

\section{Availability of data and materials}

All data supporting the conclusions of this article are included within the manuscript.

\section{Authors' contributions \\ GE was involved in data and sample collection, data analysis and interpretation, drafted and reviewed the manuscript. SG participated in data and sample collection, data analysis and drafting of manuscript. GEM managed the data, analyzed the data statistically and interpreted results critically. MGA was involved data collection, in data analysis and reviewed manuscript, MSA was engaged in data collection, interpretation of the data and reviewed the manuscript. All authors read and approved of the final version of the manuscript.}

\section{Ethics approval and consent to participate}

Ethical certificate was obtained for the Institutional Review Board of NMIMR All participants and their parents or guardians gave their consent in written form or thumb impression to participate. The District Chief Executive, the chief and opinion leaders gave permission for the study to be carried out in the selected school.

\section{Competing interests}

The authors declare that they have no competing interest.

\section{Publisher's Note}

Springer Nature remains neutral with regard to jurisdictional claims in published maps and institutional affiliations.

\section{Author details}

${ }^{1}$ Noguchi Memorial Institute for Medical Research, College of Health Sciences, University of Ghana, P.O. Box LG 581, Legon, Accra, Ghana. ${ }^{2}$ Department of Nutrition and Food Science, College of Applied and Basic Sciences, University of Ghana, P.O. Box LG 134, Legon, Accra, Ghana. ${ }^{3}$ CSIR, Food Research Institute, P.O Box m 20, Accra, Ghana.

Received: 7 March 2017 Accepted: 29 May 2018

Published online: 08 June 2018

\section{References}

1. World Health Organization. The global prevalence of anaemia in 2011 Geneva: World health organization; 2015. p. 1-6.

2. McLean E, Cogswell M, Egli I, Wojdyla D, de Benoist B. Worldwide prevalence of anaemia, WHO vitamin and mineral nutrition information system, 1993-2005. Public Health Nutr. 2009;12:444-54

3. Abdul-Raza A, Diego M, Zimmerman MB, Armar-Klemesu M, Brouwer ID Whole cowpea meal fortified with NaFeEDTA reduces iron deficiency among Ghanaian school children in malaria endemic area. J Nutr. 2012; 142(10):1836-42.

4. Egbi G. Prevalence of vitamin a, zinc, iodine deficiency and anaemia among 2 10 year- old Ghanaian children. Afr J Food Agri Nutr Dev. 2012;12(2):5946-58.

5. Ghana Demographic and Health Survey (GDHS). Ghana Statistical Service Accra, Ghana Health Service, DHS Program, ICF International Rockville, Maryland, USA. 2014

6. Ministry of Health Vitamin A Prevalence Survey (MOHVAPS 1997). In: Amoaful EF: Planning a national food-based strategy for sustainable control of vitamin A deficiency in Ghana: steps toward transition from supplementation 2001

7. Agble R. Media to help in the campaign to control anaemia. In GNA, General News, Graphic Online, February 29, 2004. Web site https://www. graphic.com.gh/news/general-news/media-to-help-in-the-campaign-tocontrol-anaemia.html. Accessed 20 Aug 2017.

8. Villalpando S, Shamah-Levy T, Ramirez-Silva Cl, Mejia-Rodriguez F, Rivera JA. Prevalence of anaemia in children 1 to 12 years of age: results from a nationwide probabilistic survey in Mexico. Int J Epidemiol. 2003;45:490-8.

9. Stoltzfus RM, Mullany L, Black RE. Iron deficiency anaemia. In: Ezzati M, Lopez AD, Rodger SA, Murray CLJ, editors. Comparative quantification of health risks: global and regional burden of disease attributable to selected major risk factors. Geneva: World Health Organization; 2005. p. 163-209.

10. Simanranga RH, Kamugisha E, Hokororo A, Kidenya BR, Makani J. Prevalence and factors associated with severe anaemia amongst under-five children hospitalized at Bugando Medical Centre, Mwanza, Tanzania. BMC Hematol. 2015;15:13.

11. Obse N, Mossie A, Gobena T. Magnitude of Anemia and associated risk factors among pregnant women attending Atenatal Care in Shella Woreda, West Arsi Zone, Oromia Region, Ethiopia. Etiop J Health Sci. 2013;23(2):165-73.

12. Schneider JM, Fujii ML, Lamp CL, Lönnerdal BO, Dewey KG, Zidenberg-Cherr S. The use of multiple logistic regression to identify risk factors associated with anemia and iron deficiency in a convenience sample of 12-36 month old children from low-income families. Am J Clin Nutr. 2008;87:614-20.

13. Woyengo TA, Nyachoti CM. Review: anti-nutritional effects of phytic acid in diets for pigs and poultry-current knowledge and directions for future research. Can J Anim Sci. 2013;93:9-21.

14. Alzain B. Anemia and nutritional status of pre-school children in north Gaza, Palestine. Int J Sci Technol Res. 2012;1(11):86-91.

15. Ahmed F, Khan MR, Jackson AA. Concomitant supplemental vitamin A enhances the response to weekly supplemental iron and folic acid in anemic teenagers in urban Bangladesh. Am J Clin Nutr. 2001;74:108-15.

16. Muslimatun S, Schmidt MK, Schultink W, West CE, Hautvast JGAJ, Gross R, Muhilal. Weekly supplementation with iron and vitamin a during pregnancy 
increases hemoglobin concentration but decreases serum ferritin concentration in Indonesian pregnant women. J Nutr. 2001;131:85-90.

17. Tanumihardjo SA. Vitamin a and iron status are improved with vitamin a and iron supplementation in pregnant Indonesian women. J Nutr. 2002;132: 1909-12.

18. World Health Organization. Global prevalence of vitamin A deficiency in populations at risk 1995-2005: WHO global database on vitamin A deficiency. Geneva: WHO Press, World Health Organization; 2009. p. 55.

19. Tontisirin K, Nantel G, Bhattacharjee L. Food-based strategies to meet the challenges of micronutrient malnutrition in the developing world. Proceedings of Nutrition Society of London. Cambridge: Cambridge University Press; 2002. p. 243-50.

20. Kwenin WKJ, Wolli M, Dzomeku BM. Assessing the nutritional value of some African indigenous green leafy vegetables in Ghana. J Anim Plant Sci. 2011; 10(2):1300-5.

21. Muhanji G, Roothaert RL, Webo C, Stanley M. African indigenous vegetable enterprises and market access for small-scale farmers in East Africa. Int J Agric Sustain. 2011;9(1):194-202.

22. Institute of Medicine. Dietary reference intakes for vitamin a, vitamin K, arsenic, boron, chromium, copper, iodine, Iron, manganese, molybdenum, nickel, silicon, vanadium, and zinc. Washington, DC: National Academy Press; 2000

23. Djuikwo VN, Ejoh RA, Gouado I, Mbofung CM, Tanumihardjo SA Determination of major carotenoid in processed tropical leafy vegetables indigenous to Africa. Food Nutr Sci. 2011;2:793-802.

24. Acho CF, Zoue LT, Akpa EE, Yapo VG, Niamke SI. Leafy vegetable consumed in Southern Côte d'Ivoire: a source of high value nutrients. J Anim Plant Sci. 2014;20(3):3159-70.

25. WHO. Growth Standards; Length/height-for-age, weight-for-age, weight-forlength, weight-for-height and body mass index-for-age: methods and development. Geneva: WHO; 2006. Web site. http://www.who.int/ childgrowth/standards/Technical-report.pdf. Accessed 12 June 2011.

26. Cheesbrough M. District laboratory practice in tropical countries Part1. Cambridge: Cambridge University Press; 1998.

27. Addo E, Egbi G. Noguchi Memorial Institute for Medical Research (NMIMR) procedure for analysing serum and breast-milk retinol. Legon: Department of Nutrition, NMIMR; 1997.

28. World Health Organization. Iron deficiency anaemia. Assessment, prevention and control: a guide for programme managers. Geneva: World Health Organization; 2001.

29. Glover-Amengor M, Aryeetey R, Afari E, Nyarko E. Micronutrient composition and acceptability Moringa Oleifera leaf fortified dishes by children in AdaEast District, Ghana. Food Sci Nutr. 2016; https://doi.org/10.1002/fsn3.395.

30. Glover-Amengor M, Aryeetey R, Owusu WB, Afari E, Nyarko A. Moringa Oleifera leaf consumption on the vitamin $A$ and heamatological status of school children in Ada-East District, Ghana. Int J Food Nutr Public Health. 2017:9(1):13-25

31. Ewusie JE, Ahiadeke C, Beyene J, Hamid JS. Prevalence of anaemia among under-5 children in the Ghanaian population: estimates from the Ghana demographic and health survey. BMC Public Health. 2014;14:626.

32. Osei-Boadi K, Lartey A, Marquis G, Colecraft E. Dietary intakes and Iron status of vegetarian and non-vegetarian children in selected communities in Accra and Cape Coast, Ghana. AJFAND. 2012;12(1):5822-42.

33. Egbi G, Steiner-Asiedu M, Saalia FK, Ayi I, Ofosu W, Setorglo J, Klobodu SS, Armar-Klemesu M. Anaemia among school children older than five years in the Volta Region of Ghana. Pan Afr Med J. 2014;17(Suppl 1):10.

34. Mwanri L, Worsley A, Ryan P, Masika J. Supplemental vitamin A improves anaemia and growth in anaemic school children in Tanzania. J Nutr. 2000; 130:2691-6.

35. Semba RD, Bloem MW. The anaemia of vitamin A deficiency: epidemiology and pathogenesis. Eur J Clin Nutr. 2002;56:271-81.

36. Semba RD, de Pee S, Panagides D, Poly O, Bloem MV. Risk factors for xerophthalmia among mothers and their children and for mother-child pairs with xerophthalmia in Cambodia. Arch Ophthalma. 2004;122:517-23.

37. Shanker AV, West KPJ, Gittelsohn J, Kotz J, Pradhan R. Chronic low intakes of vitamin A-rich foods in households with xerophthalmic children: a casecontrol study in Nepal. Am J Clin Nutr. 1996;64:242-8.

38. Tansuğ N, Polat M, Ceșme S, Taneli F, Gözmen S, Tokusuğlu Ö, Yilmaz D, Dinç G. Vitamin A status of healthy children in Manisa, Turkey. Nutr J. 2010:9:34
39. Zeba AN, Prével YM, Somé IT, Delisle HF. The positive impact of red palm oil in school meals on vitamin A status: study in Burkina Faso. Nutr J. 2006;5:17.

40. You CS, Parker RS, Swanson JE. Bioavailability and vitamin A value of carotenes from red palm oil assessed by an intrinsic isotope reference method. Asia Pac J Clin Nutr. 2002;11(suppl 7):S438-42.

41. Klotz C, de Pee S, Thorne-Lyman A, Kraemer K, Bloem M. Nutrition in the perfect storm: why micronutrient malnutrition will be a widespread health consequence of high food prices. Basel: sight andLife. 2008;2:6-13.

\section{Ready to submit your research? Choose BMC and benefit from:}

- fast, convenient online submission

- thorough peer review by experienced researchers in your field

- rapid publication on acceptance

- support for research data, including large and complex data types

- gold Open Access which fosters wider collaboration and increased citations

- maximum visibility for your research: over $100 \mathrm{M}$ website views per year

At BMC, research is always in progress.

Learn more biomedcentral.com/submissions 